\title{
Nilai-nilai filosofis dalam pendidikan agama Islam
}

\author{
Ifmawati Ifmawati a,1,* \\ a SMP Muhammadiyah Ngentak, Ngentak Banjararum Kalibawang Kulonprogo, Yogyakarta, 55672, Indonesia \\ 1 ifmawati03@gmail.com \\ * corresponding author
}

\section{ARTICLE INFO}

\section{Article History}

Received: 12 of January, 2021

Revised: 30 of January, 2021

Accepted: 31 of January, 2021

Keyword: Philosophical Values, Philosophy of Science, Islamic Education

\begin{abstract}
This article aims to explore the influence of the philosophy of science in Islamic religious education. Philosophy of science is a comprehensive study related to the foundation of science, in this article it is the science of educating Islam. The process to uncover the foundations of this knowledge is carried out in three ways, first, ontology; second, epistemology; Third, axiology. The method used in writing this article is qualitative with a descriptive approach in looking philosophically at Islamic Religious Education. Philosophical Islamic religious education is the process of consciously guiding an educator towards students so that the physical, spiritual, intellectual, and other abilities of students can increase and get better towards the creation of human beings who are reflected in individuals, families and communities who carry the values Islamic values.
\end{abstract}

\section{ABSTRAK}

Artikel ini bertujuan untuk mendalami pengaruh filsafat ilmu dalam Pendidikan agama Islam. Filsafat ilmu merupakan suatu kajian yang komprehensif terkait pondasi ilmu, dalam artikel ini adalah landasan ilmu mendidik agama Islam. Proses untuk menyibak pondisi dilakukan melalui tiga hal yang substantif; pertama secara ontologi; kedua secara epistimologi; dan ketiga secara aksiologi. Metode dalam penulisan artikel ini memakai penulisan kualitatif dengan kategori deskriptif dalam melihat secara filosofis pendidikan agama Islam. Pendidikan agama Islam secara filosofis adalah pembimbingan secara secara sacar seorang pendidik terhadap peserta didik agar unsur-unsur jasmaniah, rohaniah, intelektualitas, dan kemampuan lain yang dimilikinya, dapat bertambah dan semakin baik menuju terciptanya Insan Kamil yang tercermin dari individu, keluarga, dan masyarakat yang mengusung nilai-nilai Islami.

This is an open access article under the $\mathrm{CC}-\mathrm{BY}-\mathrm{SA}$ license. 


\section{Pendahuluan}

Ilmu dan Filsafat merupakan dua terminologi yang sering berkaitan, baik secara substansial maupun historis, karena lahirnya ilmu selalu bergantung pada peran filsafat, dan filsafat pun semakin kuat eksistensinya berkat perkembangan ilmu pengetahuan. Menurut Lewis White Beck (via Gie) [1], tujuan filsafat ilmu adalah untuk mengevaluasi dan mengkritisi cara berpikir ilmiah dan berusaha menemukan hal-hal penting dari keseutuhan upaya ilmiah. Diskusi tentang filsafat ilmu sangat signifikan karena mampu memotivasi masyarakat untuk semakin inovatif dan kreatif. Filsafat ilmu menyuguhkan semangat bagi kemajuan dan perkembangan ilmu pengetahuan serta nilai-nilai moral yang terdapat dalam seluruh ilmu dalam tingkatan ontologis, epistemologis, dan aksiologis.

Filsafat tidak selalu empiris, tetapi akan selalu bersifat logis. Sehingga dapat disebut bahwa pengetahuan filosofis logis secara otomatis akan menjadi ilmu jika telah dibuktikan secara empiris. Filsafat akan terus berusaha menemukan persoalan-persoalan baru dengan mempermasalahkan hal-hal yang telah ada (eksis). Filsafat mempunyai tugas untuk memberi dasar logis bagi kegiatan ilmiah. Kemudian ilmu akan menyempurnakannya menjadi pengetahuan yang bisa digunakan oleh manusia [2].

Di dalam Islam, paradigma ilmu pada dasarnya mengikuti inti sari dari pondasi Islam itu sendiri, yaitu holistik, sistemik, terbuka, dan adil. Namun, ilmu-ilmu yang ada saat ini merupakan hasil modernisasi, di mana ilmu dianggap bukan bagian dari agama, ilmu sekuler, dan ilmu mandiri. Di satu pihak hal ini menciptakan spesifikasi super, tetapi di sisi lain menciptakan dikotomi. Faktanya, ilmu dan agama tidak dapat dipisahkan, begitu pula wahyu dan akal.

Menurut Kuntowijoyo terdapat metodologi yang digunakan dalam perkembangan keilmuan Islam yaitu obyektifikasi dan integralisasi. Integralisasi adalah integrasi wahyu (petunjuk Tuhan dalam al-Quran dan penerapannya dalam Sunnah Nabi) dengan keberagaman ilmu manusia. Sedangkan obyektifikasi adalah menempatkan ilmu Islam sebagai rahmatan lil- 'alamin [3].

Berkaitan dengan Islam sebagai ilmu, ada tiga penjelasan yang dapat digunakan untuk memaknai Filsafat Pendidikan Islam, yaitu: (1) Filsafat adalah cara untuk menerangkan bagaimana Allah menguraikan yang haq (kebenaran) dalam bahasa yang yang dapat diterima akal manusia. (2) Pendidikan adalah kegiatan transformasi ilmu pengetahuan yang menempatkan manusia sebagai subjek, di mana kegiatan tersebut berkaitan dengan membentuk personalitas baik fisik dan non fisik. (3) Islam dimaknai sebagai sebutan bagi agama Allah yang mengandung arti pengakuan terhadap Allah dengan berserah diri dan taat menjalankan perintah-Nya sesuai dengan apa yang diajarkan Rasul-Nya. Secara keseluruhan yang dimaksud dengan filosofi pendidikan Islam adalah rancangan pemikiran tentang pendidikan yang beasaskan pada ajaran Islam [4].

Merujuk pada pemaparan di atas, di mana filsafat yang digambarkan sebagai aktifitas berpikir dianggap sejalan dengan keinginan Tuhan di dalam Islam. Oleh karena itu, artikel ini akan berupaya untuk mengkritisi bagaimana nilai-nilai yang terkandung di dalam filsafat dapat mewujudkan terbentuknya manusia sempurna (insan kamil) yang menjadi tujuan akhir dalam pendidikan agama Islam.

\section{Metode}

Pembahasan di dalam artikel ini menggunakan metode kualitatif deskriptif. Merujuk pada definisi yang dirangkum Sugiyono [5], penelitian kualitatif merupakan sebuah penelitian yang menempatkan peneliti sebagai alat utama. Pengumpulan data secara teknis dilakukan dengan menggabungkan dan menganalisis data induktif. Poerwandari menggarisbawahi bahwa penelitian kualitatif menghasilkan data yang bersifat deskriptif sekaligus mengolahnya [6]. Hal ini sejalan dengan pendapat Bogdan dan Taylor dalam Moleong di mana kualitatif ditempatkan sebagai tahapan penelitian yang memproduksi data deskriptif berupa tulisan yang berisikan kata-kata atau data verbal yang berasal dari manusia berikut perilakunya yang dapat diamati [7]. Lebih lanjut Syaodih Nana menambahkan bahwa penelitian kualitatif adalah suatu cara mendeskripsikan dan menganalisis gejala, aktivitas sosial, persepsi, peristiwa, kepercayaan, dan cara berpikir manusia secara individu dan kelompok . 
Dasar pemikiran digunakannya metode ini adalah dikarenakan penelitian ini ingin mengetahui fenomena yang ada di dalam Pendidikan Agama Islam dalam kondisinya yang alamiah, bukan dalam kondisi terkendali, laboratoris, atau eksperimen, dan mengaitkannya dengan keberadaan filsafat ilmu sebagai akar terciptanya ilmu. Data yang menjadi pembahasan adalah data yang bersumber dari berbagai literature, baik yang terkait dengan filsafat, filsafat ilmu, dan filsafat pendidikan Islam. Keseluruhan data ini kemudian dianalisis bersamaan dengan fenomena umum dalam Pendidikan Agama Islam, untuk menghasilkan jawaban bagaimana filsafat dapat menjadi jalan dalam terbentuknya insan kamil.

\section{Hasil dan Pembahasan}

Filsafat ilmu pada prinsipnya adalah kajian filosofis terhadap segala hal yang terkait dengan ilmu (pengetahuan). Dapat dikatakan bahwa filsafat ilmu merupakan cara mempelajari dan memperdalam hakikat ilmu; baik dari sifat bahan, cara mendapatkannya, maupun manfaatnya bagi hidup manusia. Ilmu dimaknai sebagai pengetahuan tentang suatu aspek yang ditata secara sistemik dengan cara tertentu yang digunakan untuk menjelaskan fenomena tertentu.

Sebagai pengetahuan, merujuk pada The Liang Gie ilmu mempunyai kekhasan tertentu, di antaranya:

\section{Empiris (dihasilkan dari observasi dan eksperimen)}

2. Sistematis (diatur secara rasional dan saling memiliki hubungan yang terikat)

3. Objektif (bebas dari prasangka dan preferensi individu)

4. Analitis (memecah masalah menjadi lebih terperinci)

5. Verifikatif (bisa dicek validitasnya) [1]

Beberapa ahli berusaha memberi definisi terhadap Filsafat Ilmu sesuai hasil pemikiran mereka sebagai landasan pengembangan filsafat. Di antara pendapat ahli tersebut adalah sebagai berikut: (1) Peter Caws; Filsafat ilmu merupakan bagian dari filsafat secara umum yang aktifitasnya mengkaji ilmu dalam aspek pengalaman manusia seutuhnya. (2) Steven R. Toulmin; Filsafat ilmu adalah disiplin ilmu yang diposisikan untuk menjelaskan berbagai hal terkait tata cara meneliti secara ilmiah, menentukan argumentasi, dan membuat asumsi metafisika untuk menilai asas validitas ilmu dari posisi logika formal, berikut metodologi praktis dan metafisis [9]. (3) Lewis White Beck; Filsafat ilmu merupakan studi dan evaluasi tata cara ilmiah untuk memahami hakikat ilmu an sich secara menyeluruh, dan perihal mempelajari metode ilmiah. Dan (4) The Liang Gie; Filsafat ilmu merupakan refleksi dari pemikiran atas berbagai hal yang berkaitan dengan pondasi ilmu pengetahuan dan keterkaitan antara ilmu pengetahuan dengan seluruh aspek kehidupan manusia [1].

Dari beberapa pendapat ahli di atas, bisa disimpulkan bahwa studi filsafat ilmu lebih mengarah pada kajian filsafat yang terkait dengan ilmu an sich, bukan di tataran struktur ilmu. Hal ini menggarisbawahi apa yang telah disinggung sebelumnya bahwa tanpa filsafat maka keberadaan ilmu sulit mencapai eksistensinya.

Filsafat ilmu yang merupakan bagian dari filsafat pengetahuan, umumnya mempunyai landasan studi filosofis dengan ciri khusus. Merujuk Jujun S. Suriasumantri [2], filsafat ilmu adalah bagian dari epistemologi yang mengkhususkan diri mengkaji hakikat ilmu. Landasan filsafat ilmu adalah kajian yang terkait dengan suatu obyek yang dipelajari oleh ilmu (ontologi), seperti apa proses memperoleh pengetahuan (epistemologi), dan seperti apa ilmu itu digunakan (aksiologi).

Dengan kata lain, ruang lingkup utama kajian filsafat ilmu sama dengan topik utama filsafat pada umumnya, yaitu: ontologi, epistemologi dan aksiologi. Secara lebih rinci definisi ketiga istilah tersebut adalah sebagai berikut:

1.Ontologi: tentang objek apa saja yang dipelajari dalam ilmu, dalam penelitian ini meliputi masalah perwujudan dan realitas (appearance and reality), termasuk bagaimana kedua hal tersebut berhubungan dengan manusia sebagai subjek. 
2. Epistemologi: tentang seperti apa proses memperoleh ilmu dan bagaimana prosedur pemerolehannya yang benar.

3. Aksiologi: terkait dengan kegunaan ilmu, seperti apa etika berkaitan dengan ilmu, dan cara menerapkan ilmu dalam kehidupan. Dari pemaparan ruang lingkup tersebut terlihat masih adanya sejumlah masalah dalam kajian filsafat ilmu [10].

Permasalahan dalam filsafat ilmu secara prinsip menunjukkan pokok-pokok pikiran dari pembahasan yang tentunya bisa termasuk ke dalam salah satu areal filsafat ilmu. Di antara permasalahan tersebut adalah sebagai berikut:
a.Persoalan metafisika terkait ilmu
b. Persoalan epistemologis terkait ilmu
c. Persoalan metodologis terkait ilmu
d. Persoalan logis terkait ilmu
e. Persoalan etis terkait ilmu
f. Persoalan seputar estetika

Kajian metafisika adalah kajian atau teori tentang eksistensi. Terminology metafisika sering juga dipadukan dengan ontologi, karena pada dasarnya metafisika juga memasukkan kajiankajian lain seperti bukti tentang keberadaan Tuhan. Yang kedua, epistemologi adalah teori pengetahuan secara general; termasuk di dalamnya studi tentang pengetahuan yang biasa, pengetahuan yang ilmiah, dan pengetahuan yang filosofis. Yang ketiga, metodologi adalah pemeriksaan terhadap cara yang digunakan oleh ilmu tertentu, mulai dari segi struktur logisnya, hingga validitas metode tersebut. Yang keempat, masalah logika berkaitan dengan studi tentang cara berpikir yang benar, terutama yang berkaitan dengan metode deduksi. Yang kelima, masalah etika yang terkait aspek moral ilmu tertentu, baik ilmu yang sekadar untuk ilmu saja, maupun ilmu yang juga harus memperhatikan kegunaan dan prinsip moral masyarakat. Yang keenam, perihal estetika terkait dimensi keindahan suatu ilmu, terutama jika diterapkan dalam kehidupan masyarakat [9].

Secara luas yang menjadi objek filsafat juga menjadi bagian objek filsafat pendidikan, yaitu yang melingkupi masalah-masalah kehidupan manusia dan alam semesta. Adapun ruang lingkup filosofi pendidikan secara sempit adalah sebagai berikut; (1) membuat patokan secara eksplisit prinsip dan inti sari pendidikan; (2) memetakan fitrah manusia sebagai subjek sekaligus objek pendidikan; (3) membuat patokan secara eksplisit keterkaitan antara filsafat, filsafat pendidikan, agama dan budaya; (4) memetakan hubungan antara filsafat, filsafat pendidikan, dan teori pendidikan; (5) Merumuskan hubungan antara filsafat negara, filsafat pendidikan, dan politik pendidikan; (6) membuat patokan sistem nilai atau muatan moral pendidikan yang menjadi tujuan pendidikan [13].

Lebih mengerucut pada filsafat pendidikan yang terkait agama, yaitu agama Islam. Filsafat pendidikan Islam sebagai bidang ilmu harus secara jelas memperlihatkan aspek kajian atau ruang lingkup bahasannya. Muzayyin Arifin memaparkan bahwa mempelajari filsafat pendidikan Islam berarti turut masuk ke dalam areal berpikir yang fundamental, sistematis, logis, dan komprehensif (universal) yang berkaitan dengan pendidikan, tidak hanya dimotivasi oleh ilmu agama Islam, tetapi mengharuskan pula mempelajari ilmu-ilmu yang sesuai [11]. Argumentasi tersebut memberikan indikasi bahwa areal filsafat pendidikan Islam adalah berbagai permasalahan yang ditemui dalam kegiatan pendidikan, seperti tujuan pendidikan, permasalahan seputar guru, metode pembelajaran, kurikulum, dan lingkungan. Oleh sebab itu, saat mempelajari filsafat pendidikan Islam seseorang akan turut pula memahami rancangan tujuan pendidikan, rancangan guru ideal, rancangan kurikulum, dan hal terkait lainnya yang dilaksanakan secara terperinci, sistematis, radikal, logis, dan universal sesuai tuntutan ajaran Islam, terutama berlandaskan Al-Quran dan al-Hadits [12].

Terkait dengan luasnya filsafat pendidikan Islam ini, lebih lanjut Muzayyin Arifin mengatakan bahwa batas ruang pemikirannya bukan pada tataran teknis operasional, tetapi seluruh aspek yang mendasari dan memberi corak susunan pemikiran yang disebut filsafat. Oleh karena itu, secara general cakupan kajian filsafat pendidikan Islam adalah pembahasan 
mendalam, sistematis, mendasar, terintegrasi, logis, komprehensif dan menyeluruh tentang berbagai rancangan, dimulai dari rumusan tujuan pendidikan, guru, kurikulum, metode, lingkungan, hingga hal lain yang berkaitan [11].

Filsafat pendidikan Islam adalah penerapan filsafat Islam untuk mempelajari dan menganalisis segala masalah pendidikan. Oleh karena itu, apa yang menjadi pokok bahasan dalam filsafat pendidikan Islam bukan hanya terkait masalah pendidikan saja, tetapi harus dipahami lebih dulu apa saja yang termasuk konten filsafat Islam. Filsafat Islam seyogyanya membahas realitas yang hakiki, hakikat nilai, dan hakikat ilmu. Atas alasan tersebut, filsafat pendidikan Islam harus membahas sejumlah hal, yaitu:

1. Cara pandang Islam terhadap realitas

2. Cara pandang Islam perihal nilai

3. Cara pandang Islam terhadap pengetahuan

4. Cara pandang Islam perihal tujuan pendidikan

5. Jalan mencapai tujuan pendidikan, yang melibatkan konten pendidikan dan runtunan pendidikan [13].

Oemar Muhammad al-Taomy al-Syaibany [14] dalam bukunya menyatakan tiga urgensi filsafat pendidikan Islam yang dijabarkan secara rinci sebagai berikut:

1.Filsafat pendidikan bisa memberi bantuan bagi para perancang (pengelola) pendidikan dan pelaksananya untuk menyusun sebuah sistem pendidikan dengan pikiran yang sehat. Ini termasuk metode dan pemecahan masalah.

2.Filsafat pendidikan bisa dijadikan dasar paling baik untuk menetapkan standar penilaian pendidikan secara keseluruhan.

3.Filsafat pendidikan Islam dapat membantu memberi pemahaman mendalam terkait pemikiran untuk berbagai faktor yaitu spiritual, sosial, budaya, politik, dan ekonomi.

Jika diberikan penjelasan yang rinci, pemikiran bersumber dari kata berpikir yang artinya runtunan, cara atau tindakan berpikir, dengan menggunakan akal pikiran untuk menyelesaikan suatu masalah dengan mempertimbangkan segala aspek dengan bijak. Dalam kamus filsafat, terminologi pemikiran mengacu pada proses aktivitas mental dan hasil-hasilnya. Definisi tersebut menggambarkan bahwa berpikir bisa dimaknai dari dua sisi, yaitu sebagai sebab dan akibat. Dari sisi pertama, berpikir bisa dimaknai sebagai proses mengolah pikiran untuk melihat gejala dan berupaya menemukan solusi dengan bijak. Sedangkan dari sisi kedua, berpikir adalah hasil dari upaya ijtihad manusia untuk membereskan segala persoalannya dalam kehidupan [15].

Jika pemikiran dimaknai sebagai sebuah runtunan, maka arah diskusi pemikiran, berikut fokus dan orientasinya berpijak pada eksplorasi epistemologis pemikiran itu sendiri. Yang maksudnya adalah pembahasan perihal pemikiran pendidikan Islam, misalnya, juga akan membahas perihal kedudukan pemikiran pendidikan Islam disandingkan dengan filsafat dan ilmu pendidikan Islam. Namun, jika dimaknai sebagai akibat maka arah pembahasan pemikiran, beserta focus dan orientasinya akan berpijak pada eksplorasi sejarah dan khazanah pemikiran yang dimaksud [15].

Pemikiran pendidikan Islam mempunyai tujuan sebagaimana yang akan dipaparkan berikut; (1) memberi bantuan untuk menemukan masalah seputar pendidikan dan pada saat yang sama juga memberi cara untuk menyelesaikannya secara sistematis, universal, radikal, spekulatif, mendalam, dan rasional. (2) memberikan informasi yang komprehensif, mendalam, dan sistematis tentang hal-hal yang harus diperhatikan dalam merumuskan dan merancang konsep pendidikan. (3) memberikan keterangan tentang runtunan pendidikan khususnya pendidikan Islam; kualitas atau kegagalan pendidikan, apakah tujuan telah terpenuhi, atau keterangan tentang kelemahan lainnya [16].

Namun, idealisme filsafat pendidikan Islam sebagaimana yang dipaparkan di atas, tidak sepenuhnya berjalan dengan baik. Setidaknya ada tiga kelemahan metodologis yang fundamental terkait pendidikan Islam, (1) pemikiran refleksi teoritis yang tidak memadai tentang makna pendidikan sehingga menghambat tugas pendidikan Islam, (2) tidak adanya pembatasan ketat 
penafsiran tentang pendidikan sehingga menimbulkan kerancuan untuk membedakan antara terminology pendidikan dan pedagogic, terutama pada sumber-sumber inti di kalangan muslim yang menyebut pendidikan Islam adalah apa yang tertanam di dalam religiusitas, spiritual, dan intelektual muslim yang diwariskan, (3) kurangnya penelitian empiris dalam mengeksplorasi praktik pedagogic dan mengembangkan kebijakan berbasis bukti lapangan [17].

Idealisme Islam yang dimaksud di sini, pada dasarnya berisikan nilai tingkah laku manusia yang dilandasi dengan keimanan dan ketakwaan kepada Allah SWT. Hasan Langgulung via Abuddin Nata menyatakan bahwa tujuan pendidikan agama seharusnya bisa mengakomodir tiga kegunaan penting agama yaitu spiritual yang berhubungan dengan iman dan keyakinan, psikologis yang berhubungan dengan perilaku individu, yaitu nilai moral, dan fungsi sosial terkait ketentuan yang mempertalikan antar sesama manusia, juga antar masyarakat dengan komunitas lain, agar tercipta hubungan yang seimbang dan harmonis [12]..

Sebenarnya, telah ada petunjuk bagi guru dalam ajaran Islam yang tertuang dalam firman Allah Swt: "Tidaklah Aku mengutusmu, Muhammad, melainkan menjadi rahmat bagi seluruh alam." Berdasarkan ayat tersebut, menurut pandangan para ahli terdapat beberapa ciri dari penjelasan-penjelasan tentang tujuan pendidikan Islam, yang paling sedikitnya sebagai berikut:

1. Membimbing manusia menjadi khalifatullah (wakil Allah) sebaik-baiknya di bumi dengan mengemban tugas menciptakan kemakmuran dan mengelola bumi sesuai dengan titah Tuhan.

2. Menuntun manusia untuk menjalankan tugasnya sebagai khalifah demi beribadah kepada Allah Swt

3. Menuntun manusia untuk berperilaku baik, agar saat menjalankan tugasnya terhindar dari penyalahgunaan.

4. Membimbing dan menuntun kemampuan pikiran, jiwa dan raganya, agar memiliki ilmu pengetahuan, akhlak, dan kecakapan yang bisa menunjang keberhasilannya dalam menjalankan tugas sebagai khalifah.

5. Menuntun manusia untuk memperoleh ketenteraman hidup di dunia dan akhirat. Oleh karena itu, jelas sekali bahwa tujuan hakiki pendidikan Islam adalah menjadikan manusia lebih baik, yang tunduk patuh kepada Allah dan dapat melaksanakan amanah dan tugas sebagai khalifatullah di muka bumi [18].

Agar pendidikan dapat terlaksana sesuai dengan tujuan yang diharapkan maka dibutuhkan sebuah metode yang merupakan cara atau langkah pelaksanaannya. Metode menjadi salah satu hal krusial yang harus dirumuskan. Herman H. Horne mendefinisikan maksud metode dalam pendidikan sebagai prosedur dalam mengajar [19]. Penggunaan satu metode atau berbagai metode yang digunakan bersamaan dapat diketahui, meskipun guru yang menggunakannya sama sekali tidak memahami perihal metode tersebut. Landasan penggunaan metode yang umum diketahui adalah "ajarilah orang lain sebagaimana orang lain ajarkan kepada Anda". Dalam rangkaian kegiatan belajar mengajar seringkali metode tersebut melekat, sehingga sering kali diabaikan oleh guru dan siswa. Oleh karena itu, meskipun tidak dipersiapkan secara sadar, metode tetap dimasukkan dalam proses pendidikan.

Mengacu pada pendapat Muzayyin Arifin, metode di dalam filsafat pendidikan adalah perlengkapan yang digunakan untuk tercapainya tujuan pendidikan [11]. Perlengkapan ini memiliki fungsi yang berbeda, (1) polipragmatik, artinya jika suatu metode dapat digunakan untuk beberapa kepentingan, maka di satu aspek dapat memberi manfaat dan berdampak positif, tetapi dapat pula menjadi sesuatu yang merugikan dan memberi dampak negatif di aspek lainnya. Contoh paling konkrit adalah media berbasis IT (teknologi informasi) yang dapat digunakan baik untuk tujuan positif maupun negatif. Sedangkan (2) monopragmatik adalah perlengkapan yang hanya dapat digunakan untuk satu kepentingan saja, salah satu contohnya adalah laboratorium. Dalam sejarah pendidikan Islam, para pendidik muslim menerapkan berbagai metode pendidikan untuk menyesuaikan dengan situasi dan kondisi yang berbeda. Ini seperti yang dicontohkan berdasarkan pemikiran para filsuf Muslim, tiga di antaranya akan dibahas pada bagian di bawah ini. Ketiga filsuf tersebut tidak menciptakan dikotomi antara nilai-nilai filosofis dan pendidikan Islam, juga tidak dikotomi antara pendidikan sekuler dan pendidikan agama, karena keduanya harus bisa berjalan beriringan dan saling menguatkan. 
Imam Al-Ghazali di dalam tulisannya menggarisbawahi bahwa seorang pendidik wajib memanfaatkan pengaruhnya dan metode yang tepat agar berhasil dalam menjalankan tugasnya [20]. Pemanfaatan pengaruh cenderung menjadi sarana untuk mengontrol siswa agar tetap berada di bawah pengawasan dan arahan guru. Kewenangan seorang guru, misalnya, merupakan alat kontrol. Pandangan yang luas dan ilmiah juga bisa menjadi alat kontrol. Dengan pengaruh kewibawaan guru beserta pandangan keilmuan yang luas, siswa dapat diarahkan, dikendalikan, dan dibentuk sesuai dengan tujuan pendidikan.

Dalam hal memberi pendidikan, al-Ghazali mengadopsi tata cara yang didasarkan pada penyeimbangan antara kemampuan berpikir logis dan kekuatan Tuhan, antara kemampuan nalar dan pengalaman sufistik yang memberi wadah bagi nalar, serta penyeimbangan antara pemikiran deduktif logis dan pengalaman empiris manusia. Menurutnya, praktik pendidikan perlu mencakup internal diri yaitu jiwa, ruh, dan hati yang merupakan bagian dari pikiran. Oleh karena itu, al-Ghazali tidak patut dikategorikan sebagai intelektual muslim yang membuat dikotomi antar-ilmu. Bahkan, ia justru ingin mengintegrasikan semua bidang ilmu dan memasukkannya ke dalam kepribadian siswa secara seimbang. Peserta didik diharapkan dapat berkembang menjadi manusia yang sempurna (insan kamil), yang dapat memadukan kecakapan berpikir logis dan kekuatan Tuhan. Pada akhirnya ia tumbuh menjadi pribadi yang kritis, sekalipun ia adalah seorang yang spiritualis. Berpikir logis diperlukan, tetapi tidak harus bertentangan dengan keberadaan alam spiritual dan ketuhanan. Tidak hanya menjadi manusia yang berpengetahuan luas tentang perkembangan hidup di dunia, peserta didik dalam pendidikan Islam juga diharapkan menjadi seorang yang spiritualis, dekat dengan Tuhan [21].

Berdasarkan pandangan empiris al-Ghazali, digambarkannya pula metode pendidikan yang dia inginkan. Di antaranya lebih ditekankan pada peningkatan sikap dan perilaku guru dalam mendidik, contohnya: guru harus menyayangi siswanya seperti anaknya sendiri, menasehati agar belajar tidak hanya untuk kepentingan diri sendiri, tetapi untuk mendapatkan ridha Allah, memotivasi siswa untuk mencari ilmu yang bermanfaat, memberi keteladanan, mengajarkan materi sesuai dengan intelektual siswa, mencoba memahami karakter setiap siswa, serta mempertajam aspek keimanannya. Guru tidak hanya berkewajiban mentransformasikan ilmu pengetahuan, tetapi juga membimbing perkembangan moral dan spiritual siswanya. Metode pendidikan Islam tidak hanya berbicara tentang berbagai cara menyampaikan teori-teori ilmu pengetahuan, tetapi juga cara anak agar dapat mengaplikasikannya dalam kehidupan, terlihat dari perilaku kesehariannya yang sejalan dengan tuntunan agama. Oleh karena itu, metode pendidikan Islam harus mencakup seluruh aspek kepribadian peserta didik.

Di sisi lain, Ibnu Khaldun memberikan landasan metodologis dalam pengajaran yang lebih bersifat psikologis, antara lain: a) tidak menyampaikan pelajaran yang sulit kepada siswa yang baru mulai belajar. Siswa harus dipersiapkan secara bertahap sesuai dengan kondisi dan tingkatan umur, b) siswa diajar hal-hal yang sederhana dan dilanjutkan secara bertahap menuju hal-hal yang lebih tinggi dan lebih sulit dengan menggunakan alat peraga dan alat bantu lainnya, dan c) guru tidak menyampaikan pengetahuan di luar kemampuan berpikir siswanya, karena dapat memicu rasa malas untuk belajar [22].

Ibn Khaldun melihat sosok peserta didik sebagai sosok yang belum matang dan belum dewasa. Anak-anak yang masih berusia dini tentunya memiliki kelemahan yang lebih banyak dibandingkan orang dewasa. Oleh karena itu, pendidikan yang disampaikan pada anak haruslah diberi secara bertahap, agar tidak terjadi hal-hal buruk yang tidak diinginkan. Guru harus mencermati berbagai sisi kepribadian setiap siswanya, membuat catatan tingkat kecerdasan dan kemampuan individu, serta membekali pengetahuan dengan pembagian yang belum tentu sama antar-siswa. Ibnu Khaldun menerapkan konsep kebebasan dan bermartabat dalam praktik pendidikan, menurutnya jika anak didik dikuasai atau ditundukkan, mereka akan kehilangan keinginan untuk berprestasi, kreatif, dan kemampuan membela diri sendiri. Sebaliknya, mereka menjadi peniru penindas mereka dan dapat melakukan hal serupa di kemudian hari [21].

Meskipun terlihat berbeda sudut pandang, metode pendidikan yang ditawarkan al-Ghazali dan Ibn Khaldun faktanya saling melengkapi. Dari pandangan al-Ghazali, seorang guru dapat belajar tentang apa yang harus dilakukannya, dan dari Ibn Khaldun belajar tentang cara melakukannya. Seluruh metode yang diajarkan al-Ghazali dan Ibnu Khaldun dapat digunakan untuk peserta didik agar dapat mencapai tujuan akhir pendidikan yaitu menjadi manusia yang sempurna (insan 
kamil). Selanjutnya metode pendidikan yang berasal dari pemikiran Ibnu Sina, menurutnya suatu materi pelajaran seharusnya dapat disampaikan kepada siswa tidak hanya dengan satu cara, tetapi dengan beragam cara sesuai dengan perkembangan psikologisnya. Menurutnya, anak harus memperhatikan pendidikan akhlaknya, budi pekerti luhur dapat dikembangkan dalam diri sejak kecil sejalan dengan kecenderungan yang baik. Ibn Sina menyarankan metode berbeda dalam memberikan materi pelajaran. Hal ini menunjukkan bahwa Ibnu Sina menaruh perhatian pada perbedaan karakter materi pelajaran yang hanya dapat disampaikan dengan menggunakan metode tertentu. Ibnu Sina juga memperkenalkan metode targhîb dan tarhîb yang dalam pendidikan kontemporer dikenal dengan reward dan threat yang artinya hadiah atau penghargaan dan ancaman atau rasa takut untuk melakukan kesalahan. Menjadi salah satu sarana pendidikan yang berbentuk penguatan positif, diharapkan dapat memberi motivasi yang baik [23].

Metode pembelajaran yang dikemukakan Ibnu Sina tidak lain adalah sebagai pelengkap pandangan dua filosof muslim sebelumnya, Al-Ghazali dan Ibnu Khaldun. Jelaslah bahwa metode sangat berperan secara fungsional dalam penyampaian materi pendidikan. Yang harus ditekankan, sejalan dengan prinsip Al-Qur'an bahwa manusia memiliki potensi istimewa baik dari aspek jasmani, rohani, dan akal. Oleh karena itu, dalam penyampaian materi pendidikan yang di dalamnya terdapat tiga aspek, yaitu kognitif, psikomotor, dan afektif, dibutuhkan suatu pendekatan pembelajaran dengan metode berbeda sesuai dengan apa yang diperlukan, termasuk menciptakan lingkungan yang dapat mendukung tercapainya keberhasilan proses pembelajaran bagi peserta didik [18].

\section{Kesimpulan}

Filsafat ilmu adalah studi mendalam tentang dasar-dasar ilmu. Untuk mengungkap pondasi atau asas-asas ilmu pengetahuan digunakan tiga pendekatan, yaitu ontologi, epistemologi, dan aksiologi. Dari ketiga pendekatan tersebut muncul filsafat pendidikan, hal ini dikarenakan pengetahuan hanya dapat disebarkan melalui pendidikan.

Agama, termasuk di dalamnya Islam, membutuhkan filsafat pendidikan untuk menyebarkan tujuan beragama bagi para pemeluknya. Meskipun sebagian pihak menganggap filsafat ataupun metode pendidikan umum termasuk liberalism dan tidak dapat digunakan untuk mendidik agama bagi anak didik, tetapi para filosof muslim berpendapat sebaliknya. Tidak ada dikotomi antara liberal dan agama dalam hal pendidikan, tidak terkecuali pendidikan agama Islam, karena pada intinya filsafat ilmu memiliki tujuan yang sama dengan pendidikan agama Islam itu sendiri.

Sebagaimana tujuan filsafat untuk menemukan kebenaran yang hakiki, baik secara rasional (kebenaran berpikir), etis (berperilaku), ataupun metafisis (hakikat keaslian), tujuan pendidikan Islampun sama belaka. Nilai-nilai filosofis sejatinya sudah tertanam dengan sendirinya dalam pendidikan Islam yang tujuan akhirnya adalah mendidik seseorang menjadi manusia sempurna (insan kamil) yang menyadari keberadaan Tuhannya, berakhlak mulia, dan berpikiran kritis dan kreatif sebagai khalifah Tuhan di muka bumi, yang mengemban tugas memelihara keberlangsungan hidup seluruh makhluk ciptaan Tuhan

\section{Referensi}

[1] T. L. Gie, Pengantar Filsafat Ilmu. Yogyakarta: Liberty, 2012.

[2] J. S. Suriasumantri, Filsafat Ilmu: Sebuah Pengantar Populer. Jakarta: Pustaka Sinar Harapan, 2005.

[3] Kuntowijoyo, Islam Sebagai Ilmu: Epistemologi, Metodologi, dan Etika. Jakarta: Teraju, 2004.

[4] M. Tolchah, "Filsafat Pendidikan Islam: Kontruksi Tipologis dalam Pengembangan Kurikulum," Tsaqafah J. Perad. Islam, vol. 11, no. 2, pp. 381-398, 2015.

[5] Sugiyono, Metode Penelitian Kuantitatif, Kualitatif dan R\&D. Bandung: Alfabeta, 2013.

[6] E. K. Poerwandari, Pendekatan Kualitatif Untuk Penelitian Perilaku Manusia. Depok: LPSP3 Universitas Indonesia, 2005.

[7] L. J. Moleong, Metode Penelitian Kualitatif, 36th ed. Bandung: Remaja Rosda Karya, 2017. 
[8] N. S. Sukmadinata, Metode Penelitian Pendidikan. Bandung: Remaja Rosda Karya, 2011.

[9] Ismaun, Filsafat Ilmu. Bandung: Penerbit UPI, 2001.

[10] S. Widyawati, "Filsafat Ilmu Sebagai Landasan Pengembangan Ilmu Pendidikan," J. Seni Budaya, vol. 11, no. 1, p. 8, 2013.

[11] H. M. Arifin, Filsafat Pendidikan Islam. Jakarta: Bumi Aksara, 2003.

[12] A. Nata, Filsafat Pendidikan Islam. Jakarta: PT. Logos Wacana Ilmu, 2001.

[13] A. H. Hermawan, Filsafat Pendidikan Islam. Jakarta: Departemen Agama Republik Indonesia, 2009.

[14] O. M. A.-T. Al-Syaibani, Filsafat Pendidikan Islam, 1st ed. Jakarta: Bulan Bintang, 2003.

[15] Mahmud and T. Priatna, Pemikiran Pendidikan Islam, I. Bandung: Sahifa, 2005.

[16] Matpari, "Tipologi Pemikiran Pendidikan Islam: Membangun Paradigma Pendidikan Sebagai Wahana Pembinaan Dan Pengembangan Peserta Didik," J. Stud. Islam, vol. 5, pp. $1-12,2018$.

[17] A. Sahin, "Critical issues in islamic education studies: Rethinking islamic and western liberal secular values of education," Religions, vol. 9, no. 11, 2018.

[18] R. Rohinah, "Filsafat pendidikan Islam; Studi filosofis atas tujuan dan metode pendidikan Islam," J. Pendidik. Islam, vol. 2, no. 2, p. 309, 2013.

[19] H. H. Horne, The Philosophy of Education. Wisconsin: Book on Demand Ltd., 2014.

[20] A. H. M. ibn M. Al-Ghazali, Ihya 'Ulumddin. Beirut: Dar el-Fikr, 1939.

[21] F. Lahmar, "Islamic education: An islamic 'wisdom-based cultural environment' in awestern context," Religions, vol. 11, no. 8, pp. 1-15, 2020.

[22] A. ar-R. I. Khaldun, Muqaddimah Ibnu Khaldun. Beirut: Dar al-Kutub al-'Ilmiyah, 1993.

[23] A. T. A. Putra, "Pemikiran Filosofis Pendidikan Ibnu Sina," Lliterasi, vol. VI, no. 2, pp. 191-201, 2015. 